\section{FUNCTIONEEL ADEMEN KUN JE LEREN}

J.J. van Dixhoorn | Functioneel ademen. Adem- en ontspanningsoefeningen voor gevorderden | Amersfoort: uitgeverij Van Dixhoorn, 2021 | 313 pagina’s | € 55,- | ISBN 9789083096018

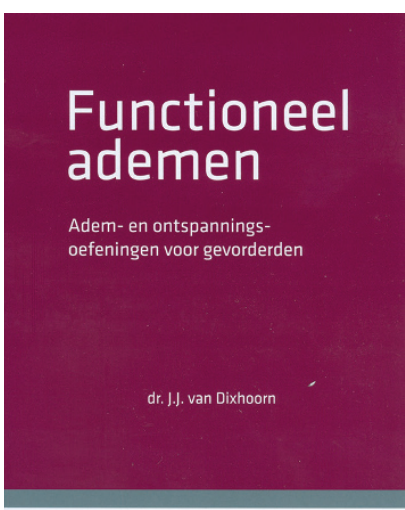

Huisartsen zien veel patiënten met ademhalingsproblemen. Zo zijn er patiënten met en zonder astma die disfunctioneel ademen. Ook na een COVID-19-infectie kunnen mensen moeite houden met ademen. In zijn nieuwe boek Functioneel ademen geeft Jan van Dixhoorn oefeningen om de ademhaling te verbeteren.

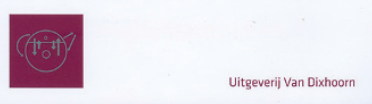

Jan van Dixhoorn - arts, wetenschapper en therapeut schreef eerder al het basisboek Ademhalingsinstructie. Dit boek is daarop een vervolg. Het is goed voorstelbaar dat klachten als ademnood, belemmering van het ademen, kortademigheid bij inspanning en angst voor ademnood leiden tot een naar gevoel en disfunc- tioneel ademen. De auteur biedt daarbij hulp. Het boek bevat bijna 50 oefeningen, deels uitbreidingen van oude en bekende oefeningen uit het basisboek en deels helemaal nieuwe. Functioneel ademen bevat ook oefeningen voor patiënten die herstellen van COVID-19 en lang last houden van hun longen. De auteur gaat terecht uit van de stelling: 'als je je ademhaling vanuit je hoofd probeert te sturen, doe je het verkeerd'. Het is fascinerend om te zien hoe verschillend mensen reageren en hoe sterk de reacties kunnen zijn op het beleven van innerlijke rust en het verminderen van de aldoor aanwezige spanning in ons. De auteur leidt de lezer heel fraai via een proefbehandeling naar het inzicht of een bepaald ademgedrag disfunctioneel is of niet. Dat is in de klinische praktijk inderdaad niet altijd makkelijk vast te stellen. Hierdoor heeft dit werk ook betekenis voor de huisarts.

Overigens kan de patiënt dit boek ook zelf doornemen (eventueel samen met de fysiotherapeut) om met de oefeningen aan de slag te gaan. Verder zijn alle oefeningen ook te downloaden vanaf www.methodevandixhoorn.com.

Al met al is dit boek een aanrader voor huisartsen en patiënten.

\section{Jean Muris}

\section{WAARDERING:}

\section{COLOFON}

Huisarts en Wetenschap [www.henw.org] wordt uitgegeven door het Nederlands Huisartsen Genootschap [NHG], de wetenschappelijke vereniging van huisartsen [www.nhg.org]. Online publicaties kunnen verschillen van de printversie. Check daarom altijd de website voor de meest actuele publicatie.

\section{Redactie}

Dr. Gijs Baaten [hoofdredacteur, huisarts], dr. Marian van den Brink [huisarts], dr. Pieter Buis [huisarts], dr. Susanne Claessen [huisarts], dr. Mirrian Hilbink [epidemioloog], dr. Annemarije Kruis [huisarts], prof. dr. Jean Muris [huisarts], Ariëtte Sanders [huisarts], Lisanne Stolwijk [huisarts] en dr. Kim van Wijck [huisarts].

\section{Redactiebureau}

Daisy Dinsbach, Anita Wittebol [secretariaat], Judith Mulder

[bladmanager], Ellen Olbers [webredactie], dr. Annet Sollie [e-redacteur], Susan Umans, Steven de Kock, Peter Lucassen, Marjolein Oosterom, Wouter Scheen [eindredactie], Margot Scheerder en Wendy Westerhof [beeldredactie]. Postbus 3231, 3502 GE Utrecht, tel. 08850655 00, redactie@nhg.org.

\section{NHG Forum}

Redactie: NHG-bureau. Met bijdragen van Lia Boelman, Fijtje Koets, Miesje Nijs, Paulien Schuttinga, Monique Verduijn, Esther Zwart, Shutterstock en Margot Scheerder [beeldredactie]. Eindredactie en contact: Susan Umans, s.umans@nhg.org, 08850655 46. NHG Forum is een uitgave van het NHGbureau.

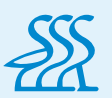

$$
\text { bohn }
$$

\section{Uitgever}

Anouk Middelkamp, Bohn Stafleu van Loghum

Postbus 246, 3990 GA Houten

Basisvormgeving: Frederik Helfrich, Deventer

Auteursinformatie: www.henw.org/voor-auteurs

\section{Advertentieverkoop}

Advertentieverkoop: adverteren@bsl.nl, tel. 030-6383603.

Advertenties behoeven goedkeuring van de redactie.

Inzenden aan: traffic@bsl.nl, tel.030-6383603.

\section{Abonnementen}

H\&W verschijnt 12 keer per jaar en wordt verspreid onder de leden van het NHG. Niet-leden kunnen zich abonneren via www.bsl.nl. Abonnementsprijs: [print + online toegang] € 274,00, online-only abonnement € 164,40, studenten $50 \%$ korting.

Abonnementen worden automatisch verlengd tenzij 2 maanden voor de vervaldatum schriftelijk opgezegd.

Bent u NHG-lid en wilt u een adreswijziging doorgeven, stuur dan een e-mail naar info@nhg.org met daarin alle relevante informatie. Informatie: Klantenservice, Postbus 246, 3990 GA Houten, tel. 0306383736 en op www.bsl.nl/klantenservice/abonnementen.

\section{Voorwaarden}

Op leveringen en diensten zijn de bij de Kamer van Koophandel gedeponeerde algemene voorwaarden van Springer Media B.V. van toepassing. Zie www.bsl.nl.

(C) 20२2 NHG

ISSN 0018-7070 